\title{
Hazine Bölümlerinin KKTC’'deki Bankaların Karlılığı Üzerine Etkilerinin Değerlendirilmesi
}

\section{Evaluation of the Significance of the Treasury Departments on Profitability of Banks in TRNC}

\author{
Demet B. Kalmaz, ${ }^{\mathrm{a},{ }^{*}}$ Mehmet Tamel ${ }^{\mathrm{b}}$ \\ a Dr. Öğr. Üyesi, Lefke Avrupa Üniversitesi, İ̈BF, Ekonomi Bölümü, Lefke/KKTC. \\ ORCID: 0000-0002-4407-5720

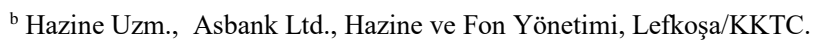 \\ ORCID: 0000-0002-4675-4436
}

\section{MAKALE BILGİSI}

\section{Makale Geçmişi:}

Başvuru tarihi: 24 Kasım 2016

Düzeltme tarihi: 02 Ekim 2017

Kabul tarihi: 17 Ekim 2017

\section{Anahtar Kelimeler:}

Bankacilık

Risk

Karlılık

Hazine Bölümü

\section{ARTICLE INFO}

\section{Article history:}

Received 24 November 2017

Received in revised form 02 October 2017

Accepted 17 October 2017

\section{Keywords:}

Banks

Risk

Profitability

Treasuary Department

\section{ÖZ}

Kuzey Kıbrıs Türk Cumhuriyeti'nde bankacılık sektörü ekonominin temel yapı taşlarından birini oluşturur. Bu çalışmanın temel amacı, ülkemizde son zamanlarda yeni oluşuma geçen bankaların hazine bölümlerinin görevlerini, önemini ve banka karlılı̆̆ı içerisindeki payını incelemektir. Bu bağlamda, Kuzey Kıbrıs Türk Cumhuriyeti Merkez Bankasından küresel kriz sonrasını kapsayan 2008 ve 2015 yılları arasındaki dönem için elde edilen veriler yorumlanmış ve bankacılık sektörünün nasıl bir gelişim gösterdiği incelenmiştir. Söz konusu dönem içerisinde bankacılık sektöründeki gelişmeler irdelenerek, sektördeki banka ve şube sayısındaki artışa paralel olarak istihdam sayısındaki artış da rakamsal olarak ortaya konmuştur. Elde edilen veriler ile hazine bölümlerinin bankacılık sektöründeki önemini sergilemek için kullanılmıştır. Bu çalışma, konu ile ilgili araştırma yapan akademisyen, öğrenci ve bankacılık sektöründen birçok kesime 1şık tutacak şekilde tasarlanmıştır.

\section{A B S T R A C T}

Banking sector is one of the main constituents of the economy of the Turkish Republic of Northern Cyprus. The main aim of this study is to examine the role, significance and the share of profits in banking sector that the newly established Treasury Departments of banks generate. In this context, the data covering the period after the global crises falling the years between 2008 and 2015 collected from the Turkish Republic of Northern Cyprus Central Bank are analyzed and interpreted to explain the recent developments of the banking sector. The increases in labour employment parallel to the increases of number of banks and branches are illustrated. With this respect, the significance of the Treasury Departments in the sector and the importance of the profits they generated were put forth. This study is designed to be guidance for the academics, students and sector members for further research on the topic.

\section{Giriş}

2012 yılında Amerika Birleşik Devletleri’ndeki (ABD) parasal genişleme politikasının sonlandırılacağının açıklanmasıyla, küresel piyasalarda ve özellikle gelişmekte olan ülke piyasalarında ciddi dalgalanmalar ve değer kayıpları görülmüştür. ABD'de başlayan kriz, sermaye akımları aracılığıyla gelişmekte olan ülkelere de yayılmış ve gelişmekte olan ülkeler küresel piyasalara olan entegrasyonları düzeylerinde, krizin etkisine daha hızlı ve daha güçlü şekilde maruz kalmışlardır (Karakurt ve
Akdemir, 2016). Gelişmekte olan ülkeler, en büyük sorunlarından biri olan cari açık problemini sermaye girişleri ile dengelemeye çalışmışlardır (Serel ve Bayır, 2013). 2008 ve 2012 yılları arasında tüm küresel piyasalarda ekonomik istikrar hâkimken 2012 Mayıs ayında ABD Federal Rezerv (FED) başkanı Ben Bernanke'nin parasal genişleme politikasının sonlandırılabileceği açıklamasıyla ekonomik istikrar sona ermiş ve küresel piyasalarda ciddi bir dalgalanma meydana gelmiştir. Bunun neticesinde makroekonomik göstergeleri iyi olan ülkeler krize karşı daha dirençli durabilirken, cari açık ve borçlanma oranları yüksek

\footnotetext{
* Sorumlu yazar/Corresponding author.

e-posta: dkalmaz@eul.edu.tr
} 
olan ülkeler krizden daha fazla etkilenmiştir. Bu dalgalanmalarla gelişmekte olan ülkelerin piyasalarından sermaye çıkışları meydana gelmiştir. Bunun sonucunda enflasyon rakamlarının yukarı, büyüme rakamlarının ise aşağı yönlü seyri ivme kazanmıştır. Bu gelișme 2012 yılıyla sınırlı kalmamış, 8 Kasım 2016 yılında ABD'de meydana gelen başkanlık seçimlerini iş adamı Donald Trump'ın kazanmasının getirdiği belirsizlik, gelişmekte olan ülke kurlarında satış baskısı yaratmıştır. Genelde küresel piyasalardan, özelde ise gelişmekte olan ülkelerin piyasalarından (Arjantin, Hindistan, Türkiye, Brezilya vb.) ciddi fon çıkışları meydana gelmiş ve bunun sonucunda bu ülke para birimlerindeki değer kayıpları artmıştır (BBC News, 2017).

ABD, 2014 Ocak ayından itibaren her ay 85 milyar USD olan tahvil alım programını 10 miyar USD azaltarak 75 milyar USD'ye çekmiştir. Bu tarihten itibaren Türkiye Cumhuriyet Merkez Bankası (TCMB) \%4,50 olan politika faizini \%10'a çekerek, TL'deki fiyat istikrarını sağlamaya çalışmıştır (Arıcan ve Okay, 2014; Köroğlu, 2004).

KKTC ekonomisine baktığımız zaman, 1983 yılında kurulan KKTC'nin ekonomik faaliyetleri ile Türkiye ekonomisine son derece bağlı olduğu görülür (Şafakl1, 2003; Tahsin, 2014). KKTC'de, TCMB tarafindan sağlanan Türk Lirası (TL) ulusal para birimi olarak kullanılmaktadır. Bu durum, KKTC'de ekonomik büyümenin ve ekonomik istikrarın sağlanmasının Türkiye ekonomisinin seyrine bağlı olması ve KKTC ekonomisinin TC'de uygulanan para politikalarından doğrudan etkilenmesi sonucunu doğurmaktadır.

KKTC Merkez Bankası verilerine göre 2016 yılsonu enflasyon rakamı önceki y1llara nazaran artarak \%10,2 olarak gerçekleşip 2013 y1lından sonra ilk kez iki haneli rakamlara ulaşmıştır. (KKTCMB, 2017a). Bu artışın temel sebebinin döviz kurlarındaki artış olduğu söylenebilir. 2014 y1lı sonunda bütçe giderlerinin gelirlerinden daha fazla olduğu ve bunun sonucunda da bütçe dengesinin 427,6 milyon TL açık verdiği görülmüştür. $\mathrm{Bu}$ olumsuz gelişmelerin yanı sıra, bankacılık sektörüne baktığımız zaman kaynak yapısı, aktif kalitesi, özkaynak yeterliliği ve karlılığından dolayı sektörün güçlü yapısını koruyarak bilanço büyüklüğünü 2016 yılı son çeyreği itibariyle Gayri Safi Yurtiçi Hasıla'nın \%1,954 katına ulaştırmış olduğu görülür. Sektörün aktif karlılığg $\% 1,65$ ve özkaynak karlılığı ise \%16,56 gibi oldukça istikrarlı ve sağlıklı bir seviyede devam etmektedir (KKTCMB, 2017a).

\section{Literatür Araştırması}

KKTC'de bankacılık sektörü ile ilgili olarak yapılmış birçok çalışmaya rastlanmaktadır. Bu çalıșmaların bir kısmı sektör karlılı̆̆1 üzerinde yoğunlaşırken (Şafaklı ve Kutlay, 2014; Bektaş, 2006; Ünal, 2011; Nwobodo, 2011; Çapl1, 2012), bir kısmı da sektör etkinliği (Yeşilada ve Yalyalı, 2016; Jenkins, 2007) ya da bankaların performans analizi (Altay ve Olkan, 2015) üzerine odaklanmaktadır. Diğer bir kısım çalışma ise KKTC'de bankacılık sektörünün gelişimini ve özellikle 2001 krizi nedenlerini ve etkilerini ortaya koymaktadır (Şafaklı, 2002a; Şafaklı, 2002b; Şafaklı, 2007; Şafaklı ve Eyyam, 2012; Şafaklı, 2010; Kanıpek ve Balıkçığlu, 2015). $\mathrm{Bu}$ çalışmalarda farklı yöntemlere başvurulmuştur. Çalışmaların bir kısmında anket ya da görüşme yöntemi ile elde edilen birincil derecede veriler analiz edilirken diğer kısmında ise ikincil derecede veriler kullanılarak sonuca ulaşılmıştır. KKTC Bankacılık Sektörü ile ilgili olarak yapılmış çalışmalar ve bulguları Tablo 1'de özetlenmektedir.

Tablo 1. Literatür Araştırması

\begin{tabular}{|c|c|}
\hline Yazarlar(Y11) & Sonuç ve Açıklamalar \\
\hline $\begin{array}{l}\text { Arasli vd. } \\
\text { (2005) }\end{array}$ & $\begin{array}{l}\text { Çalışmada, Kıbrıs'taki Türkçe ve Rumca } \\
\text { konuşulan bölgelerdeki bankalardaki hizmet } \\
\text { kalitesi karşılaştırılmıştır. Anket sonucu elde edilen } \\
\text { verilerin analizi her iki bölgedeki banka } \\
\text { müşterilerinin de beklentilerinin karş1lanamadığı } \\
\text { ortaya koymuştur. }\end{array}$ \\
\hline $\begin{array}{l}\text { Şafaklı } \\
(2007)\end{array}$ & $\begin{array}{l}\text { Çalışmada, kuzey Kıbrıs bankacılık sektöründe } \\
\text { kredi riski araştırılmış ve } 2001 \text { yılındaki bankacılık } \\
\text { krizinin önemli bir belirleyicisi olduğu ortaya } \\
\text { konmuştur. Çalışmada Merkez Bankasının veri } \\
\text { tabanından elde edilen oranlardan yararlanılarak bu } \\
\text { oranların yıllar içerisindeki seyri yorumlanmıştır. }\end{array}$ \\
\hline $\begin{array}{l}\text { Bektaş } \\
\text { (2006) }\end{array}$ & $\begin{array}{l}\text { Çalışmada, 1991-1997 yıllarını kapsayan dönem } \\
\text { için panel veri toplanarak piyasa gücünü ve etkin- } \\
\text { yapı hipotezlerini test etmek için rastlantısal etki } \\
\text { modeli kullanılmıştır. Araştırma sonucunda kuzey } \\
\text { Kıbrıs'taki mevduat piyasalarında ilgili dönem } \\
\text { içerisinde hiç bir hipotezin geçerli olmadığı ortaya } \\
\text { ç1kmıştır. }\end{array}$ \\
\hline $\begin{array}{l}\text { Jenkins } \\
(2007)\end{array}$ & $\begin{array}{l}\text { Çalışmada, } 2004 \text { ve } 2006 \text { yılları için kuzey } \\
\text { Kıbrıs'taki bankalardaki internet bankacılığının } \\
\text { etkisi araştırılmıştır. } 23 \text { bankada çalışan müdürlerle } \\
\text { yapılan görüşmeler sonucu elde edilen verilerin } \\
\text { analizi sonucunda internet bankacılığının gelişme } \\
\text { kaydettiği ortaya konmuştur. }\end{array}$ \\
\hline $\begin{array}{l}\text { Şafaklı } \\
(2010)\end{array}$ & $\begin{array}{l}\text { Çalışmada, KKTCMB'ndan elde edilen veriler } \\
\text { sonucunda bankacılık sektöründeki gelişmeler } \\
\text { ortaya konulmuş, bankacılık sektörünün karşılaştığ1 } \\
\text { sorunlar özetlenmiş ve bu sorunların çözümleri için } \\
\text { öneriler üretilmiştir. }\end{array}$ \\
\hline $\begin{array}{l}\text { Şafaklı } \\
\text { (2017) }\end{array}$ & $\begin{array}{l}\text { Çalışmada, KKTC'deki Akademisyenlerin internet } \\
\text { bankacılığı kullanmayı tercih sebepleri ortaya } \\
\text { konmuştur. Yapılan anketlerden elde edilen } \\
\text { verilerin analizi sonucunda } 7 / 24 \text { servis sunulması, } \\
\text { zaman kazanmak, banka ya da bankamatik önünde } \\
\text { beklememek, transfer işlemlerinin tamamının } \\
\text { görünür olması ve internet bankacıllığının tatminkâr } \\
\text { olması sonuçları ortaya çıkmıştır. }\end{array}$ \\
\hline Şahin (2013) & $\begin{array}{l}\text { Çalışmada, anket yöntemi kullanılarak elde edilen } \\
\text { veriler analiz edilmiş, bankacılık sektöründe hizmet } \\
\text { kalitesi açısından kadınların görsel, güvenirlik, } \\
\text { güvence ve ilgi boyutunda erkeklere göre, } \\
\text { erkeklerin ise duyarlılık boyutunda hizmet kalitesi } \\
\text { konusunda daha yüksek skora sahip olduğu ortaya } \\
\text { çkmıştır. }\end{array}$ \\
\hline $\begin{array}{l}\text { Şafaklı } \\
\text { (2002a) }\end{array}$ & $\begin{array}{l}\text { Çalışmada, literatür taraması yapılarak KKTC } \\
\text { vergi sisteminde eksikliklerin olduğu, vergi } \\
\text { etkinliğinde ise TC ile önemli farklılıklar olmadığı } \\
\text { tespit edilirken, İngiltere ve AB ülkeleri ile } \\
\text { karşılaştırıldığında ciddi farklar olduğu } \\
\text { gözlemlenmiştir. Banka krizleri sonrasında ise } \\
\text { yürütülen maliye politikalarının bütçe açığının } \\
\text { kapanmasına yönelik olup, üretimi düşürücü ve } \\
\text { Bankacılık sektörü istikrarını sağlayıcı bir etkisi } \\
\text { olmadığı görülmüştür. }\end{array}$ \\
\hline $\begin{array}{l}\text { Altay ve } \\
\text { Olkan } \\
(2015)\end{array}$ & $\begin{array}{l}\text { Çalışmada, oran ve trend analizleri kullanılarak } \\
\text { verimlilik, karlılık, aktif yapısı ve kalitesi, likidite, } \\
\text { döviz pozisyonu, büyüme, kaldıraç (leverage) ve } \\
\text { sermaye yeterlilik oranları kullanılarak performans } \\
\text { değerlendirilmesi yapılmış karşılaştırmalı analizler } \\
\text { sonucunda şubeli bankaların daha iyi bir } \\
\text { performans gösterdiği tespit edilmiştir. }\end{array}$ \\
\hline
\end{tabular}


Çalışmada literatür taraması yapılarak Kıbrıs’ta bankaların ortaya çıkışı ve tarihsel gelişimi incelenmiș Kıbrislı Türklerde bankacılığın

Kanıpek ve Balıkçığlu (2015) öncelikle tasarruf sandığı şeklinde başladığı ve zaman içinde değişimlere uğrayarak uluslararası bir boyut kazandığı tespit edilmiştir. Yapılan anket sonucunda ise bankaların bankacılık dışında sosyal faaliyetlerde bulunmalarının müşteriler gözünde olumlu bir bakış açısı yaratabileceği ortaya konmuştur.

Çalışmada, ikincil kaynaklardan elde edilen istatistikik verilerin analizi sonucunda KKTC'nin kendi para birimi olmadığından dolayı para Şafaklı ve politikasında ortaya çıkan kısır döngüler ve maliye Özdeșer politikasının KKTC ekonomisinde ne kadar önemli (2002) olduğu ortaya konulmuştur. KKTC ekonomisinde ekonomi politikalarının etkinliğinin arttırılması ve kısır döngülerin bertaraf edilmesi için öneriler sunulmuştur.

Çalışmada, ikincil kaynaklardan elde edilen veriler analiz edilmiş, KKTC'nin olası bir AB üyeliğinde kamu bankalarının uluslararası rekabet açısından

Şafaklı çok zayıf yönleri olduğu ortaya çıkmıştır. Yerel (2006) bankaların gerek sermaye gerekse teknolojik olarak güçlendirilmesi, kamu bankalarının ise özelleştirilmesi veya özerkleştirilmesi gerektiği vurgulanmıştır.

Çalışmanın, temel amacı literatür taraması yaparak KKTC'de meydana gelen banka krizlerinin neden ve sonuçlarını ortaya koymak ve bu krizlerin yeniden yaşanmaması için öneriler geliştirmektir. Kriz nedeni olarak sermaye yetersizliği,

Şafaklı makroekonomik politikalardan kaynaklanan (2002b) sorunlar, yasal düzenlemeler, holding bankalar, Merkez Bankası bilançosundaki bozulmalar, detenetimsel yetersizlik gibi etkenler olduğu ortaya konulmuştur. Ayrıca kriz sonrası yerel bankalara olan güvenilirliğin Türkiye menşeli bankalara kaydığı gözlemlenmiştir.

Çalışmada, KKTC bankacılık sektöründe Veri Zarflama Analizi yapılarak girdiye yönelik etkinlik

Yeşilada ve analizi gerçekleştirilmiş ve 2006-2014 yıllarını Yalyalı kapsayan dönem içerisinde şube bankalarının, özel (2016) sermayeli bankalara ve kamu bankalarına göre daha etkin oldukları saptanmıştır.

Çalışmada, Kuzey Kıbrıs bankacılık sektörünün gelişim süreci karșılaștırmalı olarak incelenmiștir.

Şafaklı ve Bankacılık sektörünün kriz öncesi dönemdeki Altuner yapısal ve finansal görünümünü ortaya konmuş ve (2013) yapılan analiz sonucunda sektörde meydana gelen reformların krizin atlatılmasında önemli rolü olduğu saptanmıştır.

Çalışmada, KKTC bankacılık sektöründe karşılaşılan temel sorunlar ve bu sorunların

Şafaklı giderilmesi için uygulanan proaktif ve reaktif (2003) stratejiler kısmi olarak ortaya konmuş ve uzun vadeli kalıcı sonuçların elde edilmesi için önerilerde bulunulmuştur.

Çalışmada, geleceğin potansiyel banka müşterisi olarak kabul edilebilecek 258 lisans öğrencisinden oluşan örneklemden anket yoluyla elde edilen veriler analiz edilerek, banka seçimlerinde Türk ve

Katırcıoğlu Türk olmayan ögrenciler arasında yüksek seviyede vd. (2011) fark olmadığı saptanmıştır. Gerek Türk ve gerekse de yabancı ögrencilerin banka seçimlerinde en önemli kriter olarak yakın mesafede bankamatik bulunması yer almaktadır.
Çalışmada, net faiz marjı ve faiz oranları arasındaki farkı belirleyen faktörlerin incelenmesi için 20032009 dönemlerini kapsayacak șekilde 24 ticari

Betktaş bankadan elde edilen veriler ile panel veri analizi

(2014) yapılmıştır. Kredi riski, pazar payı ve verimliğin net faiz marjı ve faiz oranları arasındaki farkı üzerinde pozitif ve anlamlı etkisi olduğu tespit edilmiştir.

Çalışmada, Kuzey Kıbrıs'ta faaliyet gösteren bankaların karlılı̆̆ını etkileyen içsel ve dışsal faktörler incelemek amacı ile 22 ticari bankanın

Kutlay 2003-2015 arası karlılı̆̆ dengesiz panel veri (2017) analizi kullanılarak saptanmıştır. Çalışma sonucunda içsel faktörlerin karlılık üzerinde önemli etkisi tespit edilirken dişsal faktörlerin karlılık üzerinde etkisi olmadığı kanısına varılmıştır.

Çalı̧̧mada, KKTC bankacılık sektörünün sahiplik

Safaklı ve açısından tablosal ve veri bazında incelenmesi Kutlay sonucunda KKTC kamu bankalarının etkinlik ve

(2014) verimlilik bakımından neo-liberal düşüncenin öngördüğü sonuçlar ile örtüştüğü tespit edilmiştir. Çalışmada, 2001-2009 arası KKTC' de faaliyet gösteren 22 bankanın 17'si için karlılık ve şeffaflık analizi yapmıştır. CAMEL analizi kullanılarak, en

Çaplı (2012) küçük kareler yöntemi ile elde edilen bulgulara göre; sermaye yeterliliği, yönetim

harcamaları/yönetim gelirler ve likiditenin aktif karlılık üzerinde anlamlı ve pozitif etkisi tespit edilmiştir.

Çalışmada, 2003-2008 arasında KKTC'de faaliyet gösteren 21 bankanın karlılığını etkileyen mikro faktörlerin Panel Veri Analizi yöntemi ile incelenmesi sonucunda likit varlıkların toplam aktiflere oranı ve borçların toplam aktiflere oranının NIM üzerinde anlamlı ve pozitif etkisi

Ünal (2011) olduğu, şüpheli alacakların toplam aktiflere oranın, mevduatların toplam aktiflere ve faiz dişı giderlerin toplam aktiflere oranının anlamlı ve negatif etkisi olduğu ve likit varlıkların toplam aktiflere oranı, borçların toplam aktiflere oranının ve faiz dışı gelirlerin toplam aktiflere oranının ROA üzerinde anlamlı ve pozitif etkisi olduğu tespit edilmiștir.

Çalışmada, 2004-2009 yılları arası KKTC' de faaliyet gösteren 22 ticari bankanın internet hizmetleri ile karlılığı arasındaki ilişkiyi

Nwobodo incelemiştir. Panel Veri analiz kullanılarak yapılan (2011) çalışmada yabancı bankaların karlılık oranının kamu ve özel bankalardan daha yüksek olduğu ortaya çıkmıştır.

Çalışmada, küresel kriz sonrasında Kuzey Kıbrıs bankacılık sektörünün sorunları ve performans Şafaklı ve incelenmiş, karlılık, mali yeterlilik, kredi riski, Eyyam likidite riski, finansal risk rasyoları kullanılmıştır. (2012) En iyi performansı şube bankalarının gösterdiği, ikinci sırada özel bankaların son sırada ise kamu bankalarının yer aldığı saptanmıştır.

2001 krizi KKTC bankacılık tarihi içerisinde çok önemli bir yere sahiptir. 2001 krizi sonrasında KKTC bankacılık sektöründe yapılan reformlar sonucunda yapısal değişiklikler meydana gelmiştir (Şafaklı ve Altuner, 2009). Şafaklı'nın 2007 yılında yapmış olduğu çalışma sonucunda 2001 bankacılık krizinin en önemli sebeplerinden birinin bankaların kredi risklerinin kontrolden çıkması olduğu tespit edilmiştir (Şafaklı, 2007; Şafaklı, 2010). Hazine bölümlerinin başlıca görevlerinden biri risk kontrolüdür. $\mathrm{Bu}$ durum, özellikle günümüz ekonomik ve siyasal koşullarında, hazine bölümlerinin sektör içerisindeki önemini ön plana çıkarmaktadır. KKTC'de bankacılık sektörü ile ilgili yapılan 
çalışmalar incelendiğinde hazine bölümlerinin işlevlerini, görevlerini ve banka karlılığına olan katkılarını ortaya koyan bir çalışmaya rastlanmamaktadır. $\mathrm{Bu}$ çalışmanın temel amacı, ülkemizde bankaların yeni oluşuma geçen ve sektör içerisindeki önemi her geçen gün artan hazine bölümlerinin görevlerini, önemini ve banka karlılığı içerisindeki payını incelemektir.

Çalışmanın ilerleyen bölümlerinde sırası ile KKTC bankacıllk sisteminin tarihsel gelişimi, sektörün yeniden yapılanma aşamaları, sektörün genel görünümü incelenmiş, KKTC'de Hazine bölümlerinin bankacılık sektörü içerisindeki yeri ve sektör karlılığına katkısı vurgulanmış ve hazine bölümlerinin geliştirilmesi için öneriler sunulmuştur.

\section{KKTC'de Bankacılı Sisteminin Tarihsel Gelişimi}

1974 yılında Kıbrıs'ta toplumların ayrılması ile birlikte kurulan Otonom Kıbris Türk Yönetimi döneminde, TC Ziraat Bankası Genel Müdürlüğü ile Otonom Kıbrıs Türk Yönetimi Yürütme Kurulu Başkanlığı arasında imzalanan anlaşma sonucunda TC Ziraat Bankası Girne Şubesi'ne Kuzey Kıbrıs'ta Merkez Bankacılığı yapma yetkisi ve Merkez bankacılığı görevleri verilmiştir (KKTC Bankalar Birliği, 2017). Kıbrıs'ta merkez bankacılığının başlangıcı kabul edilebilecek bu anlaşma ile TC Ziraat Bankası Girne Şubesi'ne, devletin haznedarlığını yapmak; para ve kredi işlerini, ticari hayatın ihtiyaçlarına ve yönetimin ekonomik politikasının amaçlarına göre düzenlemek; bankaların nakit rezervlerini muhafaza etmek; bankalar arasında meydana gelecek olan borç ve alacak ilişkilerinde takas odası hizmeti yapmak; KKTC'deki bankacılık sistemini ve bankaların çeşitli yönlerden denetimini yapmak; ülkenin döviz rezervlerini muhafaza etmek, döviz gelir-gider hesaplarını tutmak ve döviz kurlarını tespit etmek gibi merkez bankalarının sahip olduğu görev ve yetkiler verilmiştir (KKTC Bankalar Birliği, 2017; Baykal, 2007).

TC Ziraat Bankası Girne Şubesi'nin KKTC'de Merkez Bankacılığı uygulamalarını sürdürdüğü süreç içerisindeki çalışmalarda karşılaşılan eksiklik ve güçlükler, özgür bir ülkenin aktif bir ekonomi politikasının kendine ait bir Merkez Bankası ile takip ihtiyacı, 1983 yılında KKTC'nin kurulması ile birlikte bankaların çoğalması ve bunun yanında denetim işini yürütmekte olan Maliye Bakanlığının yetersiz kalması KKTC'de Merkez Bankasının kurulmasını zorunlu hale getirmiștir. Kuzey Kıbrıs Türk Cumhuriyeti Merkez Bankası (KKTCMB) uygulamalarının başlaması ile TC Ziraat Bankası Girne Şubesi'nin Merkez Bankası görevi de sona ermiştir (KKTC Bankalar Birliği, 2017).

KKTCMB, başlangıçta Maliye Bakanlığınca sağlanan 250.000.000 (İki Yüz Elli Milyon) TL sermaye ile kurulmuştur. Genelde Merkez Bankalarının yapmış olduğu para basma veya piyasaya para sunma gibi işlemler dişında tüm bankacılık işlemlerini yürütür hale gelmiştir. 2017 yılı itibarı ile KKTC'de biri kamu, on beş özel sermayeli ve altısı da şube bankası olmak üzere toplamda yirmi iki adet ticari banka faaliyetlerini sürdürmektedir (KKTCMB, 2017b). Tablo 2'de KKTC'de faaliyet gösteren ticari bankalar kuruluş tarihlerine göre sırası ile görülmektedir. Parantez içerisinde verilen ÖSB, bankanın özel sermayeli banka; ŞB, Şube Bankası ve KB ise, kamu bankası olduğunu ifade eder.
Tablo 2. KKTC'de Faaliyet Gösteren Bankalar ve Kuruluş Yılları

\begin{tabular}{lc}
\hline Banka İsimleri & Kuruluş Yılı \\
\hline Limasol Türk Kooperatif Bankası Ltd.(ÖSB) & 1939 \\
Türkiye İş Bankası AŞ(ŞB) & 1955 \\
KT Kooperatif Merkez Bankası Ltd. (ÖSB) & 1959 \\
Türk Bankası Ltd. (ÖSB) & $1972^{1}$ \\
TC Ziraat Bankası AŞ (ŞB) & 1974 \\
T Halk Bankası AŞ (ŞB) & 1978 \\
Kıbrıs Faisal İslam Bankası Ltd. (ÖSB) & 1982 \\
Kıbrıs Vakıflar Bankası Ltd. (KB) & 1983 \\
Asbank Ltd. (ÖSB) & 1986 \\
Kıbrıs İktisat Bankası Ltd. (ÖSB) & 1990 \\
Creditwest Bank Ltd. (ÖSB) & 1994 \\
Yakın Doğu Bank Ltd. (ÖSB) & 1996 \\
Şekerbank(Kıbrı)Ltd. (ÖSB) & 1996 \\
Akfinans Bank Ltd. (ÖSB) & 1997 \\
Viya Bank Ltd. (ÖSB) & 1997 \\
Universal Bank Ltd. (ÖSB) & 1998 \\
HSBC Bank AŞ (ŞB) & 2002 \\
Türkiye Garanti Bankası AŞ (ŞB) & 2004 \\
Türk Ekonomi Bankası (TEB) (ŞB) & 2007 \\
Nova Bank Ltd. (ÖSB) & 2011 \\
Kıbrıs Kapital Bank Ltd. (ÖSB) & 2012 \\
Albank Ltd. (ÖSB) & 2016 \\
\hline Kaynak: KKTCMB (2017a) & \\
\hline
\end{tabular}

Kaynak: KKTCMB (2017a)

\section{KKTC Bankacılık Sektörünün Yeniden Yapılandırılması ve Bankacılık Sistemi}

Özellikle son çeyrek yüzyılda küreselleşme olgusunun daha fazla arttığı bir dönemde finansal piyasaların birbirleriyle bütünleşmesi ve birbirlerine olan etkisi daha da artmıştır. Bu süreç içerisinde gerek kültürel gerekse ekonomik sınırların kalkması ile uluslararası bankacılık sisteminde de değişiklikler olmuştur. $\mathrm{Bu}$ nedenle artık bankaların aktif büyüklüğü değil, uluslararası standartlara ve kurallara uyumu ve işlevselliği ön plana çıkmıştır (Sayın, 2009; Adıgüzel, 2013; Bakkal ve Susam, 2008).

Genelde küresel olarak, özelde ise gelişmiş ülkelerde meydana gelen ekonomik krizler ilk etapta gelişmekte olan ülkeleri etkilemekte ve bunun sonucunda gerek ekonomik gerekse kültürel açıdan kayıplara yol açmaktadır (Sezgin, 2012). KKTC'nin bağımsız bir devlet olarak kurulduğu günden bu yana sadece Türkiye Cumhuriyeti tarafindan bağımsız bir devlet olarak tanınması ve Türkiye Cumhuriyetinin para birimi olan Türk Lirasını yerel para birimi olarak kullanması ve ekonomisinin yüksek oranda Türkiye Cumhuriyeti'nden gelen yardımlara dayanması, Türkiye'de meydana gelen ekonomik ve finansal krizlerin KKTC'yi de doğrudan etkilemesine sebep olmaktadır (Okumuş vd., 2005; Şahinkaya, 2002). Özellikle 2001 yılında Türkiye'de yaşanan kriz KKTC' nin Türkiye ile olan ekonomik bağından dolayı KKTC ekonomisini de oldukça ağır etkilemiş ve o dönemde batan bankalardan dolayı bankacılık sektöründe ciddi bir güven erozyonu oluşmuştur.

Özellikle Ticari bankalar, borçların vadesini uzatamadıkları veya vadesiz mevduatlardaki ani çekme taleplerini karşılayamadıkları zaman likidite sıkıntısına düşmektedirler. Likidite sıkıntısına düşen bankaların iflas etmesi kaçınılmaz hale gelir ki bu da Bankacılık krizlerini doğurur (Delice, 2003). Bankaları iflasa götüren en önemli sebeplerden biri 
oluşan güven kaybıdır. Kriz dönemlerinde bankalara, mevduat sahipleri, bankaya kredi veren kiși ve ya kuruluşlar ve banka hissedarları tarafından güven kaybı oluşur. Güven kaybı sonucunda bankalardan çekilen fonlar bankalar için iflasa sebep olur. Bir bankanın iflası her zaman bankacılık krizine yol açmayabilir fakat bu bankanın, bankacılık sistemi içindeki payının büyüklüğüne göre değişebilmektedir. Eğer bankanın sistem içerisindeki payı büyük ise, tek bir bankanın iflasının tüm finansal sisteme ve ekonomiye yansıması ve bankacılık krizine yol açması oldukça yüksek bir ihtimaldir (Yay vd., 2001). KKTC'de ise 1999 yılında kendini hissettirmeye başlayan bankacılık krizinin birçok bankanın iflası ile sonuçlandığı görülür.

2001 krizine kadar mevzuat zaafiyeti ile KKTC'de birçok banka kurulmuştur. Kurulan bu bankaların birçoğunun holding bankası olduğu ve ortakların bankacılık dışında da faaliyet alanları bulunduğu ortaya çıkmıştır (KKTCMB, 2017c). Kriz öncesi dönemde banka kurmak için gerekli olan sermayenin bugünkü değeri ile 50 bin TL gibi düşük bir rakama karşılık gelmesi ve banka kurma izninin siyasi otoriteye bağlı olması nedeniyle 2001 kriz dönemine kadar toplam 37 banka kurulmuştur. Tablo 3, 1989 ve 2000 yılları arasında kurulan banka sayısını vermektedir (KKTCMB, 2017c).

Tablo 3. Aralık 1989 ve Ocak 2001 Yılları Arasında Kurulan Banka Sayıs1

\begin{tabular}{lc}
\hline Dönem & Say1 \\
\hline Aralık 1989 & 13 \\
Eylül 1990 & 13 \\
Şubat 1992 & 14 \\
Mayıs 1992 & 14 \\
Mayıs 1993 & 20 \\
Haziran 1996 & 25 \\
Mayıs 1997 & 27 \\
Temmuz 1998 & 34 \\
Temmuz 1999 & 37 \\
Eylül 2000 & 39 \\
Ocak 2001 & 37 \\
\hline
\end{tabular}

Kaynak: Şahinkaya (2002)

Tablo 3'de görülen banka sayısındaki artışta ilk sırayı alanlar holding bankalarıdır. Bu bankaların kuruluş amacı, düşük maliyetli likidite (mevduat) toplayarak bu likiditeyi kendi işletmeleri için kullanmaktı (KKTCMB, 2017c). Bu bankaların yanlış izlemiş oldukları yanlış politikalar sonucunda 2001 bankacılık krizi patlak vermiş ve birçok banka tasfiye edilmiştir.

KKTC bankacılık krizinin önemli sebeplerinden biri daha önce de bahsettiğimiz gibi kredi riskinin artması ile açıklanabilir. Kredi riski, banka sermayesinin kredi kayıplarını absorbe etme kapasitesini gösterir. Kredi riski kredilerin toplam özkaynaklara olan oranı ile ölçülür (Şafaklı, 2007). Grafik 1 KKTCMB'ndan elde ettiğimiz 1984-2016 verileri kullanarak yapılan hesaplamalara göre ilgili yıllar arasındaki kredi riskini yansıtmaktadır. 1994 yılından bankacılık krizinin başlangıcına kadar bankaların kredi risk oranının artan bir seyir izlediği görülmektedir. Artan kredi riski bankaların kredi kayıplarını absorbe etme kapasitesinin bozulmasına neden olmuştur. Bu durum, bankacılık krizinde kredi riskinin rolünü açıkça ortaya koymaktadır.
Grafik 1. Banka Bilanço Büyüklük Oranlarının Yıllara Göre Dağılımı, Toplam krediler/Özkaynak.

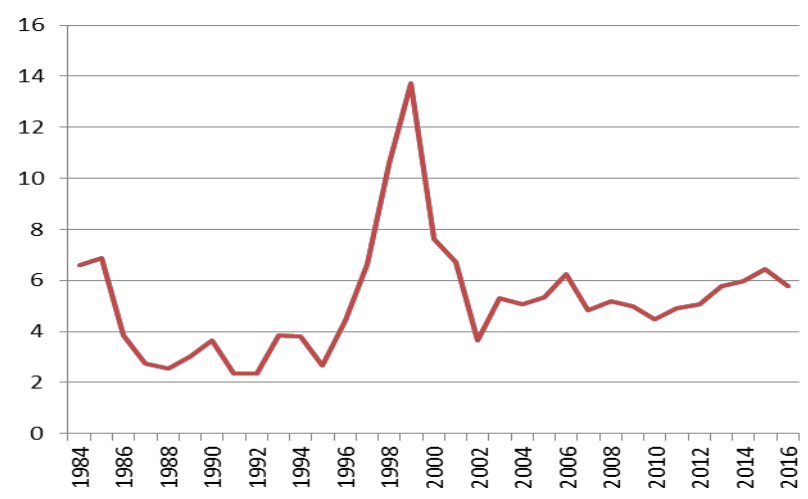

Kaynak: KKTCMB (2017d)

Türkiye'de ekonomik iklimin kötüye gitmesi ve döviz kurunda gerçekleşen artış ekonominin daralmasına yol açmış ve finansal sektörü de olumsuz etkilemiştir. Bu durum, Türkiye ekonomisine bağlı bir ekonomik yapıya sahip olan KKTC'deki bankalara yönelik artan krediyle ilgili endişelerin ciddi bir boyuta ulaşmasına sebep olmuştur. Bu durum bankacılık krizinin patlak vermesiyle sonuçlanmıştır.

2001 krizi sonrası birçok banka tasfiye edilmiş, Tasarruf Mevduatı Sigorta Fonuna (TMSF) devredilmiştir. Bu bankalar Tablo 4 yardımı ile özetlenmiştir.

Tablo 4. Tasfiye Edilen ve TMSF'na Devredilen Bankalar

\begin{tabular}{ll}
\hline Tasfiye Edilen Bankalar & TMSF'ye Devredilen Bankalar \\
\hline K.Kredi Bankası Ltd. & Kibrıs Ticaret Bankası Ltd. \\
Kıbrıs Hür Bank Ltd. & Yasa Bank Ltd. \\
Everest Bank Ltd. & Tilmo Bank Ltd. \\
Kıbrıs Yurt Bank Ltd. & Asya Bank Ltd. \\
Kıbrıs Finansbank Ltd. & Kibrıs Endüstri Bankası Ltd. \\
Kıbrıs Euro Bank Ltd. & Erbank Ltd. \\
& Rumeli Bank Ltd. \\
& Kibris Continental Bank Ltd. \\
& Denizbank Ltd. \\
\hline
\end{tabular}

Kaynak: KKTCMB (2017c)

Kriz öncesi dönemde bankaların gerek iç kontrol, gerek risk yönetimi, gerekse Hazine bölümlerinin olmadığını görmekteyiz. Ayrıca bu bankaların aktif-pasif dengelerinin olmayışı, bankaların Merkez Bankası mevzuatlarına uymayışı, kontrolsüz ve bilinçsiz faiz politikası uygulamaları, kriz dönemini atlatamayıp ya tasfiye edilmeleri veya TMSF'na devredilmeleriyle sonuçlanmıştır. Ancak kriz sonrası bankalar yeniden yapılanarak varlık ve yükümlülüklerini yerine getirmek için risk, iç kontrol ve denetim birimleri ile birlikte Hazine bölümlerini de kurmuştur. $\mathrm{Bu}$ bölümlerin kurulması ile bankaların mali tabloları Merkez Bankası mevzuatlarına uygun hale getirilmiş ve disipline dayalı bir bilanço yapısı oluşturulmuştur. Dinamik bir aktif-pasif yönetimi ile bankalar her geçen yıl karlılıklarını artırmıştır. Banka bilançolarında aktif değerlerin yaklaşık \%70'ini krediler oluşturmakta ve 2001 krizi sonrası bankaların geri dönüşü mümkün olan ve reel sektörün kalkınmasına yönelik krediler vermeye başladığı görülmektedir (KKTCMB, 2017b). Pasiflerinde bulunan mevduatlar içinse piyasa koşullarının ve Türkiye piyasasının takip edilerek uygun faiz oranları verilmeye başlanmasıyla ve mevduat müşterilerinin de 
memnuniyeti ve sektöre olan güveni artmaya başlamıştır. Bankaların Hazine bölümlerini kurması ile gerek banka sermayesi gerekse kullanılmayan fonlar daha etkin ve verimli bir şekilde kullanılmaya başlanmış bunun sonucu olarak hem bankaların kendi içinde yaptıkları düzenlemeler ile hem de Merkez Bankasının mevzuatta yaptığ değişiklikler ile bankacılık sektörü 2008 küresel krizini de başarı ile atlatmıştır (Zeren ve Demirci, 2013; Mercan, 2014).

Türkiye'de yaşanan siyasi istikrarsızlık ve buna bağlı olarak ekonomik ve finansal krizlere maruz kalan bankacıllk sektörü KKTC ekonomisinin ciddi boyutta sarsılmasına sebep olmuştur. Kriz sonrası Merkez Bankasının 2001'de çıkarmış olduğu yasa ile banka açabilmek için gereken sermaye bugünkü değeri ile 50 bin TL'den 2 milyon USD'ye çıkarılmış, Merkez Bankası yapmış olduğu denetimlerdeki aksaklıkları bankalara anında bildirerek gerekli düzenlemelerin yapılmasını zorunlu kılmıştır. Bu denetimler sonucunda gerekli düzenlemeler yapılmadığı takdirde cezai yaptırımlar da uygulamaya koyulmuştur. Böylelikle kriz sonrası yapılan mevzuat değişikliği denetimlerin etkinliği ile sağlam ve verimli bir finansal yapı oluşturulmuş ve ayni zamanda Merkez Bankası denetimi ile güvenilir bir bankacılık sektörü ortaya çıkmıştır (Zeren ve Demirci, 2013).

\section{KKTC'de Finansal Piyasaların ve Bankacilık Sektörünün Genel Görünümü}

Hazine bölümlerinin karlılığa olan etkilerine anlamak için önce finansal piyasaların ve sonra da bankacılık sektörünün global kriz ve sonrasındaki genel görünümüne kısaca değinmek faydalı olacaktır. Global krizin sona ermesi, ABD' nin makroekonomik göstergelerindeki iyileşmeler neticesinde, parasal genişleme ile küresel piyasalarda dolaşan sermaye akımlarının yeniden sistem içerisine alınması hayata geçirilmiştir. Gelişmekte olan ülkelerde ise bu sermaye akımlarının çıkışı ile para birimlerinde kurdan dolayı enflasyon üzerinde bir baskı oluşmuştur. Bu sebepten dolayı gelişmekte olan ülkelerin Merkez Bankaları para politikalarında sıkılaștırmaya giderek kendi paralarındaki değer kaybını azaltma yönüne gitmişlerdir. S1kı para politikası ile daralan talep emtia fiyatlarını yukarı yönde arttırmış ve bu da gelişmiş ülkelerde enflasyon üzerinde bir baskı yaratarak gelișmiş ülkelerdeki ihracatın azalmasına, kalıcı istihdam ve sürdürülebilir büyümenin gecikmesine neden olmuştur. $\mathrm{Bu}$ çerçevede başta Çin olmak üzere gelişmekte olan ülkelerin büyüme hızları, ABD ve EURO bölgesindeki gevşek para politikalarının ne şekilde olacağına ve portföy akımlarına bağlı hale gelmiştir (Bakkal ve Susam, 2009). 2009 yılının ilk çeyreğinde global krizin etkileri Türk Lirasında ve enflasyon oranlarında da fazlası ile hissedilmiștir. Yılın ikinci çeyreğinde Türk Lirası üzerindeki baskı azalmış ve sepet kur yılın başlarındaki seviyelere gerilese de gecikmiş kur etkisi ve geçmiş yılın ilk iki çeyreğindeki düşük enflasyon oranları sebebi ile enflasyon üzerindeki bozulmanın yıl ortasından sonra düzelmesi mümkün olabilmiştir. Kapalı bir ekonomik yapıya sahip olan KKTC'de ise global kriz Türkiye ekonomisine kıyasla daha da derinden etkisini göstermiş, ekonomik büyümede eksi rakamlar görülürken ișsizlik oranındaki artış rekor seviyelere ulaşmıştır (DPÖ, 2017). Bütün bu olumsuz ekonomik gelişmelere rağmen küresel krizin bankacılık sektöründeki etkisi çok derin hissedilmemiştir.

2016 yılı ilk çeyreğine baktığımız zaman, küresel ekonomide gelişmiş ülkelerdeki sınırlı büyümenin devam ettiği, gelişmekte olan ülkelerin ise ilk çeyreğin son dönemlerindeki portföy akımlarının sınırlı olması nedeni ile büyüme oranlarının aşağı yönde yeniden revize edildiği görülmektedir.

Merkez Bankasının 3 aylık yayınlanan bültenleri her yılın son çeyrek bülteni baz alınarak incelenmiş bunun sonucunda da 2008 yılı itibarı ile 2016 yılı son çeyreğine kadar Bankacılık sektöründe bir önceki y1la göre finansal derinleşme rakamlarının tümünde bir artış tespit edilmiştir. 2016 y1lı son çeyreğinde toplam krediler (brüt)/GSYH oranının \%117,4'e, toplam mevduat/GSYH oranının $\% 153,1$ 'e ve toplam aktif/GSYH oranının ise \%194,4'e yükseldiği tespit edilmiştir.

Tablo 5. Banka Sayısındaki Gelișmeler

\begin{tabular}{lccccccccc}
\hline & 2008 & 2009 & 2010 & 2011 & 2012 & 2013 & 2014 & 2015 & 2016 \\
\hline Kamu Bankaları & 1 & 1 & 3 & 2 & 1 & 1 & 1 & 1 & 1 \\
Özel Sermayeli Bankalar & 16 & 16 & 13 & 13 & 14 & 14 & 14 & 14 & 15 \\
Şube Bankaları & 7 & 7 & 7 & 7 & 7 & 7 & 7 & 7 & 6 \\
Toplam & 24 & 24 & 23 & 22 & 22 & 22 & 22 & 22 & 22 \\
\hline
\end{tabular}

Kaynak: KKTCMB (2017a)'den elde edilen veriler doğrultusunda hazırlanmıştır.

Tablo 6. KKTC Bankacılık Sektörünün Şube ve Personel Sayısı Gelişimi

\begin{tabular}{|c|c|c|c|c|c|c|c|c|c|}
\hline \multicolumn{10}{|c|}{ Şube Sayıları } \\
\hline Yillar & 2008 & 2009 & 2010 & 2011 & 2012 & 2013 & 2014 & 2015 & 2016 \\
\hline Kamu Bankaları & 27 & 29 & 34 & 35 & 34 & 38 & 36 & 36 & 36 \\
\hline Özel Sermayeli Bankalar & 111 & 120 & 118 & 117 & 129 & 139 & 139 & 145 & 151 \\
\hline Şube Bankaları & 32 & 35 & 40 & 44 & 45 & 47 & 45 & 46 & 45 \\
\hline Toplam & 170 & 184 & 192 & 196 & 208 & 224 & 220 & 227 & 232 \\
\hline \multicolumn{10}{|c|}{ Personel Sayıları } \\
\hline Kamu Bankaları & 558 & 562 & 549 & 552 & 537 & 561 & 524 & 518 & 548 \\
\hline Özel Sermayeli Bankalar & 1432 & 1433 & 1437 & 1459 & 1669 & 1780 & 1781 & 1827 & 1934 \\
\hline Şube Bankaları & 382 & 413 & 443 & 474 & 503 & 541 & 540 & 555 & 562 \\
\hline Toplam & 2372 & 2408 & 2429 & 2485 & 2709 & 2882 & 2845 & 2900 & 3044 \\
\hline
\end{tabular}

Kaynak: KKTCMB (2017a)'den elde edilen veriler doğrultusunda hazırlanmıştır.

Mevduatın krediye dönüşüm oranı 2016 yılı aralık ayı sonunda \%76,72 olarak gerçekleşirken, Brüt kredilerin aktifler içerisindeki payı aynı yıl \%60,39 olarak kaydedilmiştir. Aralık 2016 sonunda bankacılık sektörü 
bilanço büyüklüğünün GSYH'ye oranı \%194,45 olarak gerçekleşmiştir. Brüt kredilerin aktifler içerisindeki payı ve bankacılık sektörü bilanço büyüklüğünün GSYH’ye oranı 2008 y1lından itibaren yükselen bir seyir izlemesine rağmen, brüt kredilerin aktifler içerisindeki payı 2016 yılında düşüş kaydetmiştir. Diğer taraftan mevduatın krediye dönüşme oranı ise 2008 yılından 2014 yılına kadar yükselen bir seyir izlemiş fakat 2015 yılından itibaren düşüş gösteren bir değişism kaydetmiştir.

2016 yılı dördüncü çeyrekte finansal sağlamlık göstergelerinden olan likit aktiflerin toplam aktifler içindeki pay1 \%25,94 iken Sermaye Yeterlilik Standart Rasyosu (SYSR) \%18,03 olarak tespit edilmiştir. Likit aktiflerin toplam aktifler içindeki payının 2008 yılı itibarı ile giderek düşüş gösteren bir seyir izlediği görülmektedir. Bununla birlikte 2015 ve 2016 y1llarında yükselme kaydettiği tespit edilmiştir. SYSR ise 2008 yılından itibaren fazla iniş çıkış göstermemekle birlikte dalgalı bir seyre hâkimdir (KKTCMB, 2017b).

Bankacılık sektöründeki küresel kriz sonrasında banka sayısı ile ilgili gelişmeler Tablo 5'de özetlenmiştir. 2016 y1lında 1'i kamu, 15'i özel sermayeli ve 6'sı da şube bankası olmak üzere toplamda 22 ticari bankanın faaliyet gösterdiği görülmektedir.

2016 yılında şube sayılarının banka gruplarına göre dağılımına bakıldığında \%65'inin özel sermayeli banka, \%19,4'ünün şube bankası ve \%15,6'sının ise kamu bankası olduğu görülmektedir. 2008 y1lından itibaren banka şube sayısındaki değişim incelendiği zaman giderek artan bir seyir izlediği görülmektedir. Sektörde istihdam edilen personel sayısı ise banka şube sayısındaki artışa paralel olarak giderek artmaktadır. 2016 yılının son çeyreğinde bankacılık sektöründe istihdam edilenlerin sayısı 3044'e ulaşmıştır. Banka gruplarına göre dağılımına bakıldığında bankacılık sektöründe istihdam edilenlerin 1934'ünün özel sermayeli bankalarda, 548'inin kamu bankalarında ve 562'sinin ise şube bankalarında çalışmakta olduğu görülmektedir. Tablo 6, KKTC bankacılık sektörünün şube ve personel sayısının 2008 Küresel krizi ve sonrasında yıllık değişimini vermektedir. 2008 yılından bu yana hem KKTC Bankacılık sektöründeki şube sayısının hem de sektörde istihdam edilenlerin sayısının artış gösterdiği görülmektedir.

Tablo 6'daki bilgiler doğrultusunda bankacılık sektörünün yaratmış olduğu istihdam sayısının her geçen yıl artan bir seyir izlediğini söylemek mümkündür. Bankacılık sektöründeki olumlu gelişmelerin sebebi olarak, bankacılığın ülke içindeki saygınlığının, güvenilirliğinin ve prestijinin artmış olması gösterilebilir (Ayan, 2012). Bankalar insan kaynaklarına yapılan yatırımlarını arttırmış ve günümüz koşullarına uyum sağlayarak ülkedeki prestijini yeniden kazanmıştır (Ayan, 2012).

\section{Bankacılık Sektöründe Hazine Bölümü}

Her işletmenin olduğu gibi bankacılık sektöründe yer alan ticari bankaların da birincil amacı karını maksimize etmektir (Tunay ve Silpar, 2006; İskenderoğlu vd., 2012; Atasoy, 2007; Taşkın, 2011; Tolon, 2001; Bumin, 2009). Bankalar karlılık hedefi ile kabul edilebilir riskler içerisinde net faiz gelirlerini maksimum seviyelere çıkarmak durumundadır. $\mathrm{Bu}$ da ancak aktif-pasif yönetimi ile getiriler ve maliyetler, faizler ile vadeleri arasında dengeli bir ilişki kurarak gerçekleştirilebilir. Bankaların karlılığı net faiz gelirinin artması ile mümkündür. Bankalar net faiz gelirlerini arttırmak için ya kredi satışlarını arttırmalı ki bu en önemli faiz geliridir, ya da mevduat çıkışı sağlamalıdır (Taşkın, 2011). Hazine bölümleri banka karlılığını artırma konusunda ayrı bir birim olarak ön plana çıkmakta ve sektör içinde karlılık payını her geçen gün genişletmektedir.

Hazine bölümünün temel faaliyet alanları, bankanın tüm döviz işlemleri ve sermaye piyasası işlemlerini gerçekleştirmek, piyasa analizi yaparak ileriye dönük önlem ve tedbirleri bugünden alarak bankayı mali riskten korumak ve gerek yurtdışı, gerekse yurtiçi bankalarla yapılan tüm işlemleri kontrol etmek, üst yönetime gerek ekonomik gerekse finansal raporlar hazırlamaktır (MDN Finansal Danışmanlık, 2014).

Hazine bölümlerinin performans göstergesi olarak iki temel unsuru göz önünde bulundurmak gerekir. Bunlar, kambiyo işlemleri karı ve sermaye piyasası işlem karıdır. Kambiyo işlemlerine döviz alım-satım işlemleri girmektedir. $\mathrm{Bu}$ işlemler spot işlem, yani anında yapılan döviz alım-satım işlemi, forward işlem yani ileri tarihli yapılan işlem ve SWAP işlemidir ki o da biri spot biri forward olan ve her iki bankanın kurda anlaşması ile yapılan işlemlerdir. $\mathrm{Bu}$ işlemlerin amacı bankanın mevcut bulundurmuş olduğu döviz pozisyonunu etkin, verimli ve karlı bir şekilde kullanarak banka karlılığını arttırmaktır. Bu işlemler hem ülke içindeki bankalarla hem de yurtdışında bankanın çalışmış olduğu muhabir bankalarla yapılabilir. Sermaye piyasası işlemleri ise tahvil veya hazine bonosu alım satım işlemleridir. Tahvil, vadesi bir yıldan fazla olan borçlanma senedine, hazine bonosu ise bir yıla kadar olan borçlanma senedine denir. Hazine bölümlerinin bir diğer temel görevi bankanın varlık ve yükümlülüklerini mevzuatlar doğrultusunda yerine getirmektir. Burada sözü geçen varlıklardan kasıt bilançodaki aktifler bölümündeki kalemler yani bankanın alacakları, yükümlülüklerden kasıt ise bilançodaki pasifler bölümündeki kalemler yani bankanın ödeme yükümlülükleridir (Akan, 2008).

Hazine bölümlerinin temel amacı olan banka karlılığını arttırmanın yolu finansal piyasaları iyi araştırmak ve tanımaktan geçer. Hazine bölümleri bankanın karlılığını arttıracak yeni finansal araçlar bulmaya çalışır. Gerektiğinde düşük maliyetli ve uzun vadeli kaynaklar sağlayarak bu kaynakları verimli şekilde yöneterek gerekli görülen alanlara aktarmakla sorumludur. Hazine bölümleri bankanın aktifpasif yönetimi, döviz kurları ve faiz politikaları uygulamalarından sorumludur. Bankanın nakit akışını ve geleceğe dönük ihtiyaçlar doğrultusunda nakit akış analizlerini hazırlar. Bankanın kısa, orta ve uzun vadede kurumsal değerini arttıracak atılımlar yapar. Hazine bölümleri bu değeri arttırabilmek için mali piyasaları takip eder, beklenti taşıyarak pozisyon alır, ülke ekonomilerinin kısa, orta ve uzun vadede ekonomik büyümelerini göz önünde bulundurarak oluşabilecek riskleri minimize eder ve tek merkezde toplanan fonların etkin ve verimli şekilde kullanılmasını sağlar. Tüm bu görevleri ise üç temel başlık altında gerçekleştirir. Bunlar; pozisyon alma, risk yönetimi ve ekonomik araştırmalardır (MDN Finansal Danışmanlık, 2014)

Pozisyon alma, yönetim kurulu tarafından belirlenen limitler doğrultusunda risk tanımları belirlenerek bankanın likiditesini de göz önünde bulundurarak yapılan alım satım 
işlemleridir. Bu tür işlemler yapılırken mutlaka risk birimi ile istişare içinde ve ekonomik araştırmalar göz önünde bulundurularak yapılır. Hazine bölümleri pozisyon alarak finansal piyasalarda spekülatif amaçlı al-sat şeklinde işlem yapar ve paranın verimli bir şekilde değerlendirilmesini sağlar. Pozisyon alınırken para piyasası işlemleri, döviz piyasası işlemleri, sermaye piyasası işlemleri ve tahvil ve bono işlemlerinden oluşan mali piyasalar aracılığ ile işlem yapılır. Para piyasası işlemleri, KKTCMB aracılığı ile gecelik, aylık, üç aylık ve altı aylık vadelerle bankalar arası yapılan para alım satım işlemleridir. Döviz piyasası işlemleri, yurtdışında KKTC bankalarının çalışmış oldukları muhabir bankaların hazine bölümleri ile yapılan döviz alım satım işlemleridir. Sermaye Piyasası İşlemleri, tahvil ve bono kağıdı şeklinde, KKTC bankalarının yurtdışındaki muhabir bankaların hazine bölümleri ile yapılan gerek TCMB hazine kağıdı gerekse özel sektör kağıdı, alım satım işlemleridir.

Risk yönetimi, bankanın yapmış olduğu faaliyetlerden dolayı meydana gelebilecek risklerin tanımlanması, ölçülmesi, izlenmesi ve kontrol edilmesidir. Hazine bölümünün görevi bankanın gelecekteki nakit akışlarını ve var olan pozisyonların taşımış olduğu piyasa risklerini izlemek, kontrol altında tutmak ve gerektiğinde riski daha fazla büyümeden değiştirmeye yönelik politikalar üretmek ve limitler doğrultusunda maruz kalınan risklerin tanımlanmasını, değerlendirilmesini ve kontrol edilmesini sağlamaktır. Risk yönetimi kapsamına giren riskler kur riski, vade riski, likidite riski ve faiz riskidir (Okay, 2002). Kur riski, bankanın yapmış olduğu döviz işlemlerinden kaynaklanan zarar etme riskidir ve kurlarda meydana gelen değişimler sonucu bankanın uğrayacağı riski tanımlar. Burada kurlara endeksli gelir ve giderler etkileneceklerdir. Vade riski bankanın varlıkları (alacakları) ile yükümlülükleri (borçları) arasındaki vade farklılıklarından doğan risktir. Bu vade farkı sebebiyle nakit akım tablosunun planlandığı gibi olmaması ve finansmanın oluşturulamaması sonucu meydana gelen risktir. Likidite riski, bankanın yükümlülüklerini zamanında yerine getirememesi veya gelen kredi talebine cevap verememesi sonucu oluşan riskdir. Faiz riski ise faiz geliri kazandıran aktiflerin getirisinin düşmesi veya faiz gideri oluşturan pasiflerin giderlerinin artması ile oluşabilecek dengesizlikten kaynaklanan risktir. Faiz oranlarındaki hareketlilik bankanın değerlerini ve karlılığını büyük ölçüde etkileyebilir (Özçelik, 2006). Risk yönetimi, kur riski yönetimi, faiz riski yönetimi, likidite riski yönetimi ve vade uyumu riski yönetimi doğrultusunda gerçekleştirilir. Kur riski yönetimi bankaların yabancı para varlık ve yükümlülüklerinin yönetimine özel bir önem verilmesi gerekliliğinden yalnızca varlık yükümlülük toplamı üzerinden yapılmamalı, bunun yanı sıra yabancı paraların türlerine göre alt dağılımları dikkate alınmalıdır. Belli para birimleri cinsinden bankanın net olarak kısa ya da uzun pozisyonda olup olmadığı, döviz kuru riskinin boyutlarının belirlenmesi açısından önem taşımaktadır. Sonraki aşama ise bankanın spot, forward ya da swap işlemleri aracılığıyla net pozisyonlarındaki döviz ve vade uyumsuzluğunu gidermeleri gerekmektedir (Akpak, 1995). Faiz riski yönetimi, piyasa faiz oranlarının değişmesinin bankalar için risk yaratmasından dolayı önem arz etmektedir. Faiz oranı riski, faiz oranlarında meydana gelen değişimler sebebiyle finansal araçların değerlerinde ortaya çıkardığı değişimler sonucu firmaların nakit akımlarının, bilançolarının aktif ve pasif yapılarının üzerinde yarattığı olumsuz etkiler olarak tanımlanabilir. Özellikle ülkemizdeki bankalar uzun vadeli aktiflerini finanse ederken finansal piyasadan topladıkları kısa vadeli fonları kullanmaktadırlar. Kısa vadeli fonların faiz oranlarında gerçekleşebilecek aşırı yükselmeler bankaları olumsuz etkilemektedir. Faiz oranlarında meydana gelen dalgalanmaların sebepleri olarak; para arzında ortaya çıkan değişimler, fon arz ve talebindeki değişimler, para politikası, piyasa beklentileri, getiri beklentileri, güvenilirlik ve pazar likiditesi gösterilebilir. Likidite riski yönetimi, bir bankanın yükümlülüklerini yerine getirecek likiditeye sahip olmaması, nakit giriş-çıkışları arasındaki dengesizlikler, kaynak ve bunların kullanımlarında vade uyumsuzluğundan kaynaklanan fonlama yükümlülüğünü makul bir maliyetle yerine getirememesi, yükümlülüklerini yerine getirememesi sebebiyle varlıklarını piyasa fiyatının altında bir fiyattan elden çıkarma durumuyla karşı karşıya kalması sonucu karşılaşılan riski ortadan kaldırmayı hedefler. Vade uyumu, toplanan mevduatın vadeleri ile krediler ve diğer fonlamaların tarihlerinin aralarında uyum olmasını ifade etmektedir. Vade uyumuyla yatırımlar yapılırken, mevduatlar ve ödemelerin aynı vadeleri göz önünde bulundurulacak ve böylece vade uyumu sağlanarak fonlama riski yok edilebilecektir (Özçelik, 2006).

Hazine bölümleri riskleri azaltmak ve etkin bir şekilde yönetebilmek için türev ürünleri kullanır. Bu ürünler; forward işlemleri, opsiyon işlemleri ve swap işlemleridir. Forward işlemleri, forward sözleşmesi, sözleşme tarihinde belirlenmiş bir fiyattan, sözleşme konusu belirli miktardaki ekonomik değerin (döviz, mal, menkul kıymet gibi) sözleşmede belirtilen tarihte alınması ya da satılması konusundaki bir işlemdir. Opsiyon işlemleri, opsiyon sözleşmeleri, belirli bir vadede ya da vadeye kadar, belirli bir varlığı, belirli bir miktarda, belirli bir fiyattan alma ya da satma hakkı veren sözleşmelerdir. Swap, bir paranın ya da finansal varlığın, aynı anda spot piyasalarda ve forward piyasalarda işlem görmesidir. Swap işleminde bir anlamda, bir vadenin başka bir vade ile değişimi söz konusudur (Güngörmüş, 2001).

Ekonomik araştırmalar ise ekonomik gelişmeleri izleyip analiz ederek gerek pozisyon alma gerekse var olabilecek riskleri ölçmek için yapılan araştırmalardır. Hazine bölümleri ekonomik araştırmalar yaparak geleceğe yönelik yön belirler. Bunu yapmak için de finans enstrümanları ile ilgili en iyi getiriyi sağlayacak enstrümanı bulur, makroekonomik gelişmelerin ve bu gelişmelerin banka üzerindeki etkilerini araştırır; sektör, ülke ve pazar analizi yapar, firsat ve tedbirlerin öngörülebilirliğini artırma yolları bulur (MDN Finansal Danışmanlık, 2014).

Hazine bölümleri için en önemli unsurlardan bir tanesi de banka fonlarının azami getiriyi sağlayacak şekilde etkin ve verimli olarak değerlendirilmesidir. Hazine bölümleri ekonominin ve finans piyasalarının nabzını tutan bölümlerdir. Kısacası Hazine bölümleri aktif-pasif dengeleme, riskten kaçınma, büyüme ve değer yaratmaya yönelik bankanın geleceğe dönük çalışmaların yapıldığı bölümlerdir. Banka içinde karar alınırken muhasebe bölümü ile koordinasyon içinde hareket edilir. Böylelikle alınacak her kararın, atılacak her adımın araştırılmış, risk faktörü minimize edilmiş, sağlam, geleceğe yönelik ve hata payı indirgenmiş kararlar olması sağlanır ki bu da başarıyla 
sonuçlanmasına zemin hazırlar (MDN Finansal Danışmanlık, 2014).

KKTC'de Bankacılık sektörü içerisinde hazine bölümünün öneminin anlaşılabilmesi için Hazine bölümlerinin yıllık olarak elde ettiği kar incelenmiştir. Bunun için de hazine bölümlerinin görevleri içerisinde olan sermaye piyasası ve kambiyo işlemleri sonucu elde edilen kar incelenmiş ve bankacılık sektörü içerisinde hazine bölümlerinden elde edilen karın payı hesaplanmıştır. Bunun sonucunda KKTC'de bankacılık sektöründe hazine bölümlerinin sektör karlılı̆̆ içerisindeki önemi ortaya konmuştur. 2012 yılı itibarı ile Sermaye Piyasası işlemleri ve Kambiyo Karı giderek arttığı ve 2016 yılına gelindiği zaman 104.392 bin TL'ye ulaştığı tespit edilmiştir. KKTCMB'den elde edilen veriler doğrultusunda hazırlanan Grafik 2 bize bankacıllk sektöründeki Hazine bölümleri tarafından 2008 ve 2016 yılları arasında yapılan işlemler neticesinde oluşan yıllık toplam karı göstermektedir.

Grafik 2. 2008-2016 yılları arasında Hazine Bölümü Karı (binTL)

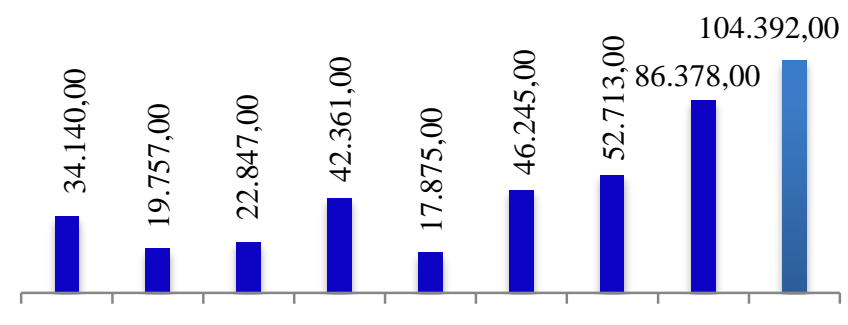

200820092010201120122013201420152016

Kaynak: KKTCMB (2017a)'den elde edilen veriler doğrultusunda hazırlanmıştır.

Grafik 3'de ise sektörün 2008 ve 2016 yılları arasındaki karlılık performansını göstermektedir. Ülke içerisinde ve uluslararası arenada yaşanan çeşitli siyasi ve ekonomik sebeplerden ötürü banka karlılıklarının düşüş gösterdiği fakat bu düşüşlerin ani ve sert düşüşler olmadığı bankacılık sektörünün 2008 yılından 2016 yılına kadar olan dönem içerisinde genel olarak yükselen bir seyir izlediği görülmektedir.

Grafik 3. Bankacılık Sektörünün 2008-2016 yılları arasındaki Karl111k Performans1

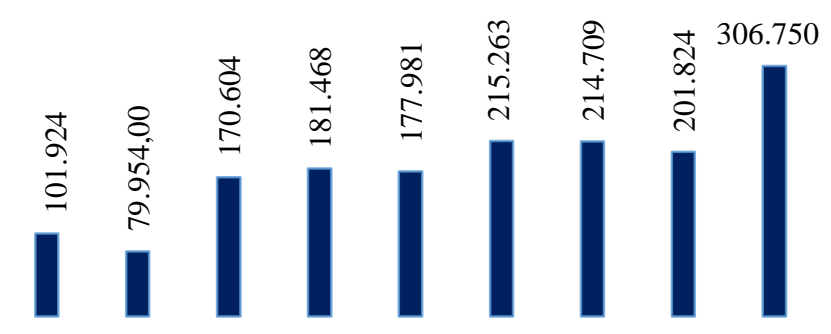

200820092010201120122013201420152016

Kaynak: KKTCMB (2017a)'den elde edilen veriler doğrultusunda hazırlanmıştır.

Grafik 4'de ise hazine bölümleri işlemleri tarafindan 20082016 yılları arasında elde edilen karın bankacılık sektörü dönem karı içindeki payı yıllık olarak hesaplanıp sunulmuştur.
Grafik 4. Hazine İşlemlerinin Bankacıllk Sektörü Dönem Karı İçindeki Payı

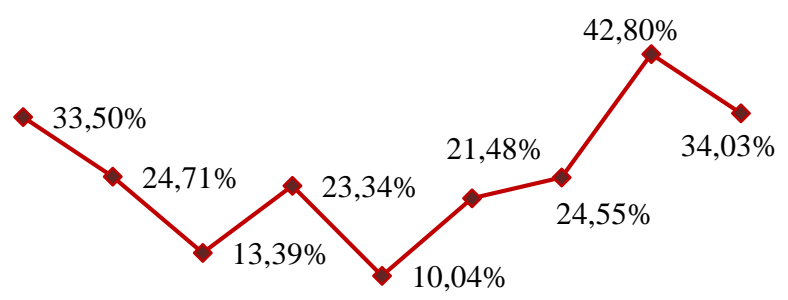

200820092010201120122013201420152016

Kaynak: KKTCMB (2017a)'den elde edilen veriler doğrultusunda yazarlar tarafindan hesaplanmıştır.

Grafiklerden de anlaşılacağı üzere Hazine bölümlerinin banka karlılığındaki payı 2012 yılından itibaren yükselme yönündedir. 2015 yılına gelindiği zaman bir önceki yıla göre oldukça $\operatorname{arttığ1}$ ve $\% 42,80$ seviyesine ulaştığ edilmiştir. Grafik 4'de sunulan veriler ile kıyaslandığı zaman bankacılık sektöründe elde edilen toplam kar azalırken hazine bölümlerinin karının yine de $\operatorname{arttığ1~ve~bu~sebepten~}$ dolayı da banka karlılığı açısından daha da önemli bölümler haline geldiği görülmektedir. Gelişen bankacılık sektörü ile birlikte hazine bölümlerinin de bu gelişim içerisinde yerini alması ve her geçen yıl karlılıkta daha büyük bir paya sahip olması beklenmektedir.

\section{Sonuç ve Değerlendirme}

Bankacılık sektörü gerek finansal fon hareketlerinden gerekse ekonomik gelişmelerden ilk ve en çok etkilenen sektörlerin başında gelmektedir. Sektörün daha güçlü ve dayanıklı bir yapıya sahip olması ve krizlere karşı hazırlıklı olabilmesi ancak sağlam teknolojik altyap1, sık1 takip kontrol ve dinamik bir organizasyon ile mümkündür. Bunu da bankaların hazine bölümleri piyasa araştırması ve ekonomik gelişmeleri yakından takip ederek yapabilir. Bu da ancak işinde uzman, eğitimli ve tecrübeli personelin bilgi birikimi paralelinde oluşmaktadır.

KKTC Bankalarının Hazine bölümlerinin tek görevinin döviz fiyatlaması olduğuna dair genel bir önyarg1 oluşmuştur. Fakat işin gerçeği bu bölümler bankanın tüm nakit akışlarını, faiz politikalarını ve döviz fiyatlamalarını yaparak bankaya değer katma yönünde kendi içinde vizyon ve misyon belirleyen bölümlerdir. Hazine bölümlerinin temel görevi bankanın varlık ve yükümlülüklerini yerine getirerek statik bir bilanço yerine dinamik bir bilanço yönetimi ile azami kar sağlamaktır. Bu da ancak sürekli bir iş takibi ve raporlama ile yapılabilir.

Kar odaklı çalışan Hazine bölümleri karlılığı arttırmak için birçok finansal enstrüman kullanarak bunun sonucunda da yılsonu banka karlılığında ciddi bir paya sahip olurlar. Hazineciliğin temel prensibi elinde bulundurmuş olduğu fonu gerek Merkez Bankası mevzuatları gerekse banka limitleri dahilinde etkin ve verimli bir şekilde kullanmaktır. Buradaki etkin ve verimlilikten kasıt piyasa şartlarını da gözeterek azami getiriyi sağlayacak şekilde değerlendirmektir. $\mathrm{Bu}$ da ancak disiplinli bir iş takibi, ekonomik araştırma ve deneyimle yaratılabilecek bir değerdir. Hazine bölümleri fon yönetimi yanında piyasa araştırması ile pozisyon alır ve disiplin içerisinde işlem yapar. İşlemin yapılmasının akabinde hangi seviyede kar 
realizasyonu yapacağı veya hangi seviyede zararın durdurulacağ 1 belirlenmelidir. Böylelikle banka karlılığ daimi olur ve riski de minimuma indirgenebilir.

Yapılan bu araştırma neticesinde hazine bölümlerinin temel görev ve sorumlulukları açıklanırken KKTC bankacılık sektöründe hazine bölümlerinin karlılık içerisindeki payının önemi ortaya konmuştur. Günümüzde KKTC'de henüz yeni gelişmekte olan hazine bölümlerine verilen önemin artması durumunda gelecek dönemlerde banka müşterilerine ihtiyaçları doğrultusunda farklı finansal enstrümanları sunarak daha aktif roller alıp banka karlılı̆̆ına katkısı artabilecek ve gelişen sektörle birlikte ülke ekonomisine katma değer yaratma konusunda önemli bir yere sahip olabilecektir.

\section{Notlar}

${ }^{1}$ Aslen 1925 'te Lefkoşa İslam İddihar Bankası Ltd. adı altında bir Limited Şirket olarak banka olarak faaliyet göstermeye başlamıştır. 1938 yılında bankanın adı Lefkoşa Türk Bankası Ltd. olarak değiştirilmiştir. 1972 yılında 'Lefkoşa' sınırlamasının kaldırılması ile yeni durumuna uygun olarak, ada bütününe hitap eden Türk Bankası Ltd. adını almıştır (Türk Bankası, 2017).

\section{Kaynakça}

Adıgüzel, M. (2013). Ekonomik Küreselleşmenin Türkiye Ekonomisine Etkileri. Akademik Bakış Dergisi, (35), 120.

Akan, B. (2008). Likidite Riski Ölçümü. Bankacılar Dergisi, $66,66-81$.

Akpak, S. (1995). Uluslar arası Bankacılık ve Finansal Sistemler, İstanbul.

Altay, O., \& Olkan, L. A. (2015). 2009-2013 Döneminde KKTC'deki Ticari Bankaların Performans Analizi. EUL Journal of Social Sciences, 6(2), 59-75.

Araslı, H., Katırcioğlu, S. T., \& Mehtap-Smadi, S. (2005). A comparison of service quality in the banking industry: Some evidence from Turkish- and Greek-speaking areas in Cyprus. International Journal of Bank Marketing, 23(7), 508-526.

Arıcan, A., \& G. Okay (2014). Ekonomik İstikrarsızlık Ortamında Merkez bankalarının Uyguladığı Para Politikaları ve Türkiye Örneği. İktisat Araştırmaları Dergisi, 1(1), 1-50.

Atasoy, H., \& Aydoğan, K. (2007). Türk Bankacilik Sektöründe Gelir-Gider Analizi ve Karlilik Performansının Belirleyicileri. Uzmanlık Yeterlilik Tezi. Ankara: TCMB, Bankacılık ve Finansal Kuruluşlar Genel Müdürlüğü.

Ayan, E. (2012). Türk Bankacılık Sektöründe İstihdam Analizi ve İstihdamın Arttırılması Olanakları. Business and Economics Research Journal, 3(1), 41-57.

Bakkal, U., \& Susam, N. (2008). Kriz Süreci Makro Değişkenleri ve 2009 Bütçe Büyüklüklerini Nasıl Etkileyecek?. Maliye dergisi, 155, 72-88.

Baykal, C. M. (2007). Hukuki Boyutlarıyla Finansal Krizler. Bankacılar Dergisi, 60, 33-48.
BBC News (2017). 2017 yılına en kötü başlangıcı Türk Lirast yaptı. (Erişim: 24.04.2017), http://www.bbc.com/turkce/haberler-turkiye-38582255.

Bektas, E. (2006). Test of market structure and profitability in liberalizing the deposit market: the case of North Cyprus. Problems and Perspectives in Management, 4(2), 62-67.

Bumin, M. (2009). Türk Bankacilik Sektörünün Karlilik Analizi: 2002-2008. Maliye Finans Yazılarl, 1(84).

Çapl1, B. N. (2012). Profitability and Transparency in the North Cyprus Banking Industry. Doctoral Dissertation. North Cyprus: Eastern Mediterranean University.

Delice, G. (2003). Finansal Krizler: Teorik ve Tarihsel Bir Perspektif. Erciyes Üniversitesi İktisadi ve İdari Bilimler Fakültesi Dergisi, (20), 57-81.

DPÖ (2017). Ekonomik Ve Sosyal Göstergeler 1977-2016. (Erişim: 14.05.2017), http://www.devplan.org/Esos-Tr1.html

Güngörmüş, A. (2001). Uluslararası Piyasalardaki Gelişime Paralel Olarak Günümüzde Kullanılan Finansman Teknikleri. (Erişim: 24.04.2017), http://www.biriyilik.com/odevler-kaynaklar/iktisatisletme-ve-ekonomi/uluslararasi-piyasalardaki-gelisimeparalel-olarak-gunumuzde-kullanilan-finansmanteknikleri-6874.html\#.VHWTxq1xmUk

İskenderoğlu, Ö., Karadeniz, E., \& Atioğlu, E. (2012). Türk bankacılık sektöründe büyüme, büyüklük ve sermaye yapısı kararlarının karlılığa etkisinin analizi. Eskişehir Osmangazi Üniversitesi İktisadi ve İdari Bilimler Dergisi, 7(1), 291-311.

Jenkins, H. (2007). Adopting Internet Banking Services in a Small Island State: Assurance of Bank Service Quality. Managing Service Quality, 17(5), 523-537.

Kanıpek, K., \& Balıkçığlu, İ. (2015). Kıbrıs’ta Bankaların Ortaya Çıkışı, Gelişimi ve Günümüz Bankacılık Dışı Faaliyetlerin Kamuoyu Üzerindeki Etkisi. AVRASYA Uluslararası Araştırmalar Dergisi, 3(6), 174-184.

Karakurt, B., \& Akdemir, T. (2016). Küresel Finansal Krizinin Devlet Borçlarına Etkisi: Gelişmiş ve Gelişmekte Olan Ülkeler Açısından Bir Değerlendirme. Sosyoekonomi, 24(29), 225-255.

Katırcıoğlu, S., Fethi, S., Unlucan, D., \& Dalc1, I (2011). Banking Selection factors in the banking industry: An empirical investigation from potential customers in Northern Cyprus. Acta Oeconomica, 61(1), 77-89.

KKTC Bankalar Birliği (2017). Üye Bankalar/Tarihsel Bilgiler, 2017. (Erişim: 24.04.2017), http://www.bankalarbirligi.org/SPhERE/cPortal/kkbb/la youts/content.jsp?pName=bankatarihselbilgiler\&pMenu $=2$

KKTCMB (2017a). 2016 4. Çeyrek Bülteni. (Erişim: 24.04.2017), http://www.kktcmerkezbankasi. org/yayinlar/bulten-2014-1-a.zip

KKTCMB (2017b). Tüketici Fiyatlarl Endeksi 2016 Dönemi. (Erişim: 24.04.2017), http://www.devplan .org/T\%c3\%bcfe/Tfe-Tur/Endeks\%20(2016).html 
KKTCMB (2017c). KKTC Merkez Bankası 2002 Yıllık Raporu. (Erişim: 24.04.2017), http://www. kktcmerkezbankasi.org/tr/yayinlar/yillik-raporlar

KKTCMB (2017d). KKTC Merkez Bankası 2017 Ylllı Raporu. (Erişim:

24.04.2017), http://www.kktcmerkezbankasi.org/tr/yayinlar /yillik-raporlar

Köroğlu, E. (2004). Merkez Bankasına Alternatif Bir Yaklaşım Olarak Para Kurulu Sistemi, Dünyadaki Uygulamaları ve Türkiye'de Uygulanabilirliği. Yüksek Lisans Tezi. Isparta: Süleyman Demirel Üniversitesi.

Kutlay, K. (2017). Kuzey Kıbrıs'ta Banka Karlığını Etkileyen Faktörler: Ampirik bir Çallşma. International Conference on "Scientific Cooperation for the Future in Economics and Administrative Sciences", Thessaloniki, 6th-8th September 2017.

MDN Finansal Danışmanlık (2014). Hazine ve Fon Yönetimi. (Erişim: 22.05.2014), http://www.mdntr.com/documents/FonYönetimi.pdf

Mercan, M. (2014). Ekonomik Büyümenin Belirleyicileri ve 2008 Krizi: Orta Asya Ülkeleri ve Türkiye Ekonomisi İçin Panel Veri Analizi. Yönetim ve Ekonomi: Celal Bayar Üniversitesi Íktisadi ve İdari Bilimler Fakültesi Dergisi, 21(1), 125-142.

Nwobodo, J. C. (2011). Internet Banking in Terms of Profitability: The Case of Northern Cyprus Banks. Master of Science Thesis. North Cyprus: Eastern Mediterranean University.

Okay, E. (2002). Türk Bankacılık Sektöründe Risk ve Kriz . Ístanbul Ticaret Üniversitesi Dergisi, 1(2), 95-122.

Okumuş, F., Altınay, M., \& Araslı, H. (2005). The impact of Turkey's economic crisis of February 2001 on the tourism industry in Northern Cyprus. Tourism Management, 26, 95-104.

Özçelik, O. (2006). Bankacılıkta Risk Analizi, Yönetimi ve Riskten Korunma. Yüksek Lisans Tezi. Edirne: Trakya Üniversitesi.

Sayın, Ş. K. (2009). Türk Bankacılık Sisteminde Bilanço Dışı İşlemler ve Risk Yönetimi Açısından Değerlendirilmesi. Dokuz Eylül Üniversitesi İktisadi ve İdari Bilimler Fakültesi Dergisi, 24(1), 15-41.

Serel, A., \& M. Bayır (2013). 2008 Finansal Krizinde Para Politikası Uygulamaları: Türkiye Örneği. Yönetim ve Ekonomi Araştırmaları Dergisi, 19, 59-80.

Sezgin, Z. (2012). Küresel Krizin İkinci Perdesi: 2011 Avrupa Borç Krizi. İşletme Araştırmaları Dergisi, 4(2), $141-150$.

Şafaklı, O. V. (2002a). KKTC'de Banka Krizleri Açısından Kamu Finansmanının Etkinliği. Uludağ Üniversitesi Íktisadi ve İdari Bilimler Fakültesi Dergisi, 11(2), 65-84.

Şafaklı, O. V. (2002b). Kuzey Kıbrıs Türk Cumhuriyeti’nde (KKTC) Banka Krizleri Üzerine Literatürel Bir Çalışma. Yakın Doğu Üniversitesi İ̈BF Dergisi, 105-115.

Şafaklı, O. V. (2003). Basic Problems of the Banking Sector in the TRNC with Partial Emphasis on the Proactive and
Reactive Strategies Applied. Doğuş Üniversitesi Dergisi, 4(2), 217-232.

Şafaklı, O. V. (2006). KKTC'nin olası AB üyeliği karşisinda kamu bankalarinin stratejik analizi. Cukurova Üniversitesi Sosyal Bilimler Enstitüsü Dergisi, 15(1), 313-332.

Şafaklı, O. V. (2007). Credit Risk Assesment for the Banking Sector of Northern Cyprus. Journal of Yasar University, 2(6), 615-630.

Şafakl1, O. V. (2010). Problems and Measures for the Turkish Cypriot Financial Sector with particular emphasis on Banking Sector. International Journal of Business Management and Economic Research, 1(1), 8597.

Şafaklı, O. V. (2017). Perceptions of Academicians towards the Reason of using Internet Banking: Case of Northern Cyprus. EUL Journal of Social Sciences, 7(1): 197-202.

Şafaklı, O. V., \& Altuner, T. (2009). Comparative Outlook on the Pre and Post Crisis Periods for the Banking Sector of Turkish Republic of Northern Cyprus (TRNC). Journal of Yasar University, 4(16), 2573-2610.

Şafaklı, O. V., \& Eyyam. Ç. (2012), A research on the problems and financial performance of banking sector in Northern Cyprus after global financial crisis. African Journal of Business Management, 6(24), 7272-7286.

Şafaklı, O. V., \& Kutlay, K. (2014). KKTC Bankacılık Sektörü Sahiplik Yapısının Neo-Liberal Dönüşüm Kapsamında Değerlendirilmesi. Neo-Liberal Dönüşüm: Boyutlart ve Sonuçlarl, Lefke Avrupa Üniversitesi.

Şafaklı, O. V., \& Özdeşer, H. (2002). KKTC Ekonomisinin Genel Analizi. Doğuş Üniversitesi Dergisi, 5, 151-171.

Şahin, K. (2013). Cinsiyete göre Bankacılık sektöründe Hizmet Kalitesi üzerine bir çalışma. LAÜ Sosyal Bilimler Dergisi, 6(1), 34-48.

Şahinkaya, S. (2002). KKTC finansal Piysalarındaki gelişmeler Üzerine Bazı Gözlemler. İçinde: Oktar Türel (Ed.), Akdeniz'de Bir Ada: KKTC'nin Varoluş Öyküsü. Ankara: İmge Kitapevi.

Tahsin, E. (2014). Kuzey Kıbrıs Özelinde Neoliberal Dönüşümün Boyutları, LAÜ Sosyal Bilimler Dergisi, 5(2), 78-95.

Taşkın, D. (2011). Türkiye'de Ticari Bankaların Performansını Etkileyen Faktörler. Ege Akademik Bakış Dergisi, 11(2), 289-298.

Tolon, M. (2001). Ticari Bankalarda Pazarlama Stratejilerinin Uygulanması ve Türkiye'deki Ticari Bankalar Üzerine Bir Alan Çalıșması. Verimlilik Dergisi, 4, 63-88.

Tunay, K. B., \& Silpar, A. M. (2006). Türk Ticari Bankacıllk Sektöründe Karlılığa Dayalı Performans Analizi-I. Türkiye Bankalar Birliği, Araştırma Tebliğleri Serisi 2006-01.

Türk Bankası (2017). Tarihçe. (Erişim: 24.04.2017), https://www.turkishbank.net/tarihce/ 
Ünal, H. (2011). Bank Specific Determinants of Net Interest Margin and Profitability at Turkish Republic Of Northern Cyprus (TRNC) Banking Sector. Master of Science in Banking and Finance Thesis. TRNC: Near East University.

Yay, T., Yay, G.G., \& Yılmaz E. (2001). Küreselleşme Sürecinde Finansal Krizler ve Finansal Düzenlemeler. İstanbul Ticaret Odasi Yayınlarl, 2001-47, İstanbul, 2001.

Yeşilada, T., \& Yalyalı, P. (2016). KKTC'de Bankacılık Sektöründe Şube ve Personel Sayisindaki Gelişmeler ile Veri Zarflama Analizi Yöntemi Kullanılarak Yapılan Etkinlik Analizi Çalışması, Lefke Avrupa Üniversitesi Sosyal Bilimler Dergisi, 7(1), 27-49.

Zeren, F., \& Demirci, Ş. (2013). Yerel ve Küresel Krizler Işı̆̆ında Basel II Kriterlerinin Türk Bankacılık Sektörü Üzerine Etkileri: 2001-2010 Veri Analizi. Niğde Üniversitesi Íktisadi ve İdari Bilimler Fakültesi Dergisi, 6(2), 17-27. 